Check for updates

Cite this: RSC Adv., 2018, 8, 27417

\title{
Evaluation of a novel low-carbon to nitrogen- and temperature-tolerant simultaneously nitrifying- denitrifying bacterium and its use in the treatment of river water
}

\begin{abstract}
Peng Jin, (D) *a Yinyan Chen, ${ }^{c}$ Zhanwang Zheng ${ }^{b c}$ and Qizhen Du*a
In this study, a simultaneously heterotrophic nitrifying-aerobic denitrifying bacterium, designated KSND, was newly isolated from a lake wetland. Its removal efficiencies for $160 \mathrm{mg} \mathrm{L}^{-1}$ ammonium, $105 \mathrm{mg} \mathrm{L}^{-1}$ nitrate, and $8.39 \mathrm{mg} \mathrm{L}^{-1}$ nitrite were $86.56 \%, 74.52 \%$, and $100 \%$ in $24 \mathrm{~h}$, with removal rates of $5.77 \mathrm{mg} \mathrm{L}^{-1} \mathrm{~h}^{-1}$ for $\mathrm{NH}_{4}{ }^{+}-\mathrm{N}$, $3.26 \mathrm{mg} \mathrm{L}^{-1} \mathrm{~h}^{-1}$ for $\mathrm{NO}_{3}{ }^{-}-\mathrm{N}$, and $0.35 \mathrm{mg} \mathrm{L}^{-1} \mathrm{~h}^{-1}$ for $\mathrm{NO}_{2}{ }^{-}-\mathrm{N}$. The bacterium retained $\sim 63 \%$ of its maximal removal rate at $10{ }^{\circ} \mathrm{C}$ and $56 \%$ of its maximal removal rate at a carbon to nitrogen $(\mathrm{C} / \mathrm{N})$ ratio of $4: 1$, with no nitrite accumulation. Gene-specific PCR indicated the absence of the key genes for nitrification and denitrification, encoding hydroxylamine oxidoreductase and nitrite reductase, respectively, suggesting that KSND achieves effective nitrogen removal by another pathway. KSND was used to treat river wastewater by culturing it in a floating bed bioreactor. Ammonia nitrogen decreased significantly from $8.76 \mathrm{mg} \mathrm{L}^{-1}$ initially to $1.87 \mathrm{mg} \mathrm{L}^{-1}$ in 90 days, with no $\mathrm{NO}_{3}{ }^{-}-\mathrm{N}$ or $\mathrm{NO}_{2}{ }^{-}-\mathrm{N}$ toxicants, indicating the great potential utility of KSND in future full-scale applications in the treatment of low- $\mathrm{C} / \mathrm{N}$ wastewater.
\end{abstract}

Received 1st June 2018

Accepted 26th July 2018

DOI: $10.1039 / \mathrm{c} 8 \mathrm{ra0} 04697 \mathrm{~b}$

rsc.li/rsc-advances
Recently, a group of bacteria capable of simultaneous nitrification and denitrification were reported..$^{9-11}$ These heterotrophic bacteria display higher growth rates than autotrophs and can use organic substrates as sources of carbon and energy to convert ammonium into nitrogenous gas under aerobic conditions. ${ }^{\mathbf{1 2}}$ Importantly, these nitrogen removal processes could be carried out in the same reaction pool, and did not require the combined action of multiple classes of microorganisms. Although SND bacterial isolates have been reported, ${ }^{\mathbf{9}, 13}$ they pose great challenges because the removal efficiency of such bacteria is significantly inactivated in low-temperature or low-C/N wastewater environments, limiting their application. Therefore, further novel microbial resources with excellent tolerance of extreme environment must be exploited and characterized.

We report a novel bacterial isolate capable of simultaneous nitrification and denitrification that efficiently removes nitrate, nitrite, and ammonia. We determined the tolerance of this bacterium for high-strength inorganic nitrogen, low temperatures, and low-C/N wastewater. The functional biomarker genes involved in the known pathways of nitrification and denitrification were not detected with PCR. The performance of strain KSND as an inoculum for removing nitrogen from polluted rivers was examined.

\section{Material and methods}

\subsection{Isolation of strain and culture media}

The bacterium KSND was isolated from lake-wetland sediment in the city of Lin'an, Zhejiang Province, China. $1 \mathrm{~mL}$ sediment 
sample was added to $100 \mathrm{~mL}$ of sterile deionized water and incubated at $30^{\circ} \mathrm{C}$ for $1 \mathrm{~h}$. After four 10 -fold serial dilutions, the sample was inoculated on MM plates with $2.0 \mathrm{~g} \mathrm{~L}^{-1} \mathrm{KNO}_{3}$ and $5 \mathrm{~g} \mathrm{~L}^{-1}$ sodium citrate at $30{ }^{\circ} \mathrm{C}$ for $24 \mathrm{~h}$. A bacterium with excellent nitrogen removal capability was obtained through shake flask experiments, and named KSND for further study.

The modified medium MM $\left(0.2 \mathrm{~g} \mathrm{~L}^{-1} \mathrm{MgSO}_{4} \cdot 7 \mathrm{H}_{2} \mathrm{O}, 1.0 \mathrm{~g} \mathrm{~L}^{-1}\right.$ $\mathrm{KH}_{2} \mathrm{PO}_{4}, 2.0 \mathrm{~mL}$ of trace element solution) was used in the nitrogen removal experiments. Ammonium chloride, ammonium nitrate, sodium nitrate, sodium nitrite and glucose were added as indicated. The trace element solution contained (per liter): $50 \mathrm{~g}$ of EDTA-2Na, $2.2 \mathrm{~g}$ of $\mathrm{ZnSO}_{4}, 5.5 \mathrm{~g}$ of $\mathrm{CaCl}_{2}, 5.06 \mathrm{~g}$ of $\mathrm{MnCl}_{2} \cdot 4 \mathrm{H}_{2} \mathrm{O}, 5.0 \mathrm{~g}$ of $\mathrm{FeSO}_{4} \cdot 7 \mathrm{H}_{2} \mathrm{O}, 1.1 \mathrm{~g}$ of $\left(\mathrm{NH}_{4}\right)_{6} \mathrm{MO}_{7} \mathrm{O}_{24} \cdot 4 \mathrm{H}_{2} \mathrm{O}$, $1.57 \mathrm{~g}$ of $\mathrm{CuSO}_{4} \cdot 5 \mathrm{H}_{2} \mathrm{O}$, and $1.61 \mathrm{~g}$ of $\mathrm{CoCl}_{2} \cdot 6 \mathrm{H}_{2} \mathrm{O}$, at pH 7.0.

\subsection{Assessment of nitrification and denitrification performance}

KSND cells were incubated in MM with $5 \mathrm{~g} \mathrm{~L}^{-1}$ glucose, and then cultured at $37{ }^{\circ} \mathrm{C}$ with shaking at $200 \mathrm{rpm}$ for $16 \mathrm{~h}$ as the seed culture $\left(\sim 6.7 \pm 0.4 \times 10^{7}\right.$ colony-forming units per $\left.\mathrm{mL}^{-1}\right)$. Flasks (500 mL) containing $100 \mathrm{~mL}$ of $\mathrm{MM}$ were inoculated with $1 \mathrm{~mL}$ of the seed culture and incubated at $30^{\circ} \mathrm{C}$ with shaking at $200 \mathrm{rpm}$. For the nitrogen removal analysis, either $160 \mathrm{mg} \mathrm{L}^{-1}$ $\mathrm{NH}_{4} \mathrm{Cl}, 105 \mathrm{mg} \mathrm{L}^{-1} \mathrm{KNO}_{3}, 8.39 \mathrm{mg} \mathrm{L} \mathrm{KNO}_{2}$, or $50 \mathrm{mg} \mathrm{L}^{-1}$ $\mathrm{NH}_{4} \mathrm{NO}_{3}$ was used as the sole nitrogen source. To evaluate the efficiency of high-strength ammonium removal, KSND was incubated in modified $\mathrm{MM}$ in the presence of $\mathrm{NH}_{4} \mathrm{Cl}$ (final concentration $20-1000 \mathrm{mg} \mathrm{\textrm {L } ^ { - 1 }}$ ) as the sole nitrogen source. Unless otherwise stated, all the experiments were conducted at $\mathrm{C} / \mathrm{N} 8$, initial $\mathrm{pH} 7.0$, culturing temperature $35^{\circ} \mathrm{C}$ and shaking speed $200 \mathrm{rpm}$. The optical density at $600 \mathrm{~nm}\left(\mathrm{OD}_{600}\right)$ was used to monitor cell growth. The concentrations of ammonium, nitrate, and nitrite were determined with Nessler's reagent spectrophotometry at $420 \mathrm{~nm}, \quad N$-(1-naphthalene)diaminoethane spectrophotometry at $410 \mathrm{~nm}$, and ultraviolet spectrophotometry at $540 \mathrm{~nm}$, respectively. Total nitrogen (TN) was determined with the standard UV spectrophotometry method (DR6000, Hach, America). All the experiments were performed in triplicate.

\subsection{Degenerate primer design and PCR amplification}

To design the degenerate primers, a neighbor-joining phylogenetic analysis was used to determine the evolutionary relationships of all hydroxylamine oxidoreductase and dissimilatory nitrite reductase sequences available in the National Center for Biotechnology Information nonredundant protein sequence database. The representtaive hydroxylamine oxidoreductase (Hao) or dissimilatory nitrite reductase (NirS) enzymes were used to construct multiple sequence alignments with the Clustal $\mathrm{X}$ program. Conserved regions were used to design the following degenerate primer pairs. JBNirS1001F (CGTGGTGGGAAAYTAYTGGCCKCC)/JBNirS-1242R (CAYGAYGGHGGHTGGGAC) and JBHAO-170F (GTATGAVGCGYTGGTNAAGCGYTA)/JBHAO-939R (TGGAACTGGRAHGTHCVTCTCAAG) were used to identify nirS and Hao genes of KSND genome DNA by gene-specific PCR, respectively.
The PCR reaction was performed with the following program: $3 \mathrm{~min}$ at $94{ }^{\circ} \mathrm{C} ; 32$ cycles of $30 \mathrm{~s}$ at $94{ }^{\circ} \mathrm{C}, 30 \mathrm{~s}$ at $50{ }^{\circ} \mathrm{C}$ and $60 \mathrm{~s}$ at $72{ }^{\circ} \mathrm{C} ; 5 \mathrm{~min}$ at $72{ }^{\circ} \mathrm{C}$ and a hold period at $4{ }^{\circ} \mathrm{C}$. Metagenomic DNA extracted from the lake sediments was used as the control template.

\subsection{Identification of strain KSND}

The gene encoding 16S rDNA of KSND was amplified with PCR using the universal primers pair $27 \mathrm{~F}$ (AGAGTTTGATCCTGGCTCAG) and 1492R (TACGGCTACCTTGTTACGACTT). To determine the evolutionary relationship of this strain KSND with established denitrifying bacterium, 16S rRNA sequence of KSND was compared to 13 representative bacterial denitrifies from the non-redundant (NR) nucleic acid sequence database (NCBI), using neighbor-joining phylogenetic analysis. One thousand bootstrap replications were performed using the MEGA software (MEGA 5.0).

\subsection{Assessment of nitrogen removal in river ecological restoration}

Xinqiao River, located in Hangzhou (Zhejiang, China), runs through a residential area, and the ammonia concentration in the river was $\sim 9 \mathrm{mg} \mathrm{L}^{-1}$ (chemical oxygen demand $\sim 127 \mathrm{mg} \mathrm{L}^{-1}$, $\mathrm{pH} 7.8$, temperature $13-27^{\circ} \mathrm{C}$ ). KSND cells were cultured in $\mathrm{MM}$ medium at $37{ }^{\circ} \mathrm{C}$ with shaking at $200 \mathrm{rpm}$ for $16 \mathrm{~h}$ as the seed cultures, and then stored at $4{ }^{\circ} \mathrm{C}$. $20 \mathrm{~L}$ seed culture was mixed with $10 \mathrm{~L} \mathrm{MM}$ medium and $10 \mathrm{~L}$ river water, with an aeration for $8 \mathrm{~h}$. The mixtures were added into the bioreactor carried by floating-bed, and $950 \mathrm{~L}$ water and $10 \mathrm{~L}$ GT medium (glucose and trace element solution) were added with continuous aeration. The extensive culture of KSND was automatically controlled to rule out $\sim 500 \mathrm{~L}$ with the floating-bed moving in the whole river $(786 \mathrm{~m} \times 6 \mathrm{~m})$, and then $500 \mathrm{~L}$ of water was replenished to the bioreactor every $24 \mathrm{~h}$. The GT medium of $10 \mathrm{~L}$ was also automatically controlled to add into the bioreactor. The water was sampled at six equidistant positions in the river and tested every 7 days, as described above.

\subsection{Nucleotide sequence accession numbers}

The nucleotide sequence has been deposited in the Genbank database under accession number MH155426.

\section{Results and discussion}

3.1. Characterization of KSND's capacity to remove $\mathrm{NH}_{4}{ }^{+}-\mathrm{N}$, $\mathrm{NO}_{3}{ }^{-}-\mathrm{N}$, and $\mathrm{NO}_{2}{ }^{-}-\mathrm{N}$

The characteristics of the nitrification and denitrification abilities of KSND are shown in Fig. 1. Cell growth showed similar trends on the three sole nitrogen sources, with the highest $\mathrm{OD}_{600}$ values of $2.65-2.84$ at $24 \mathrm{~h}$. The ammonium concentration decreased rapidly from $160 \mathrm{mg} \mathrm{L}^{-1}$ initially to $21.52 \mathrm{mg} \mathrm{L}^{-1}$, and the corresponding removal efficiency was $86.56 \pm 1.12 \%$ after $24 \mathrm{~h}$ in culture (Fig. 1a). The nitrification rate was $5.77 \mathrm{mg} \mathrm{L}^{-1} \mathrm{~h}$ for $\mathrm{NH}_{4}{ }^{+}-\mathrm{N}$, which was higher than that of Klebsiella pneumoniae CF-S9 $\left(4.30 \mathrm{mg} \mathrm{L}^{-1} \mathrm{~h}^{-1}\right) .{ }^{9}$ Analysis of the nitrogen balance showed that $31.1 \%$ of the initial $\mathrm{NH}_{4}{ }^{+}-\mathrm{N}$ 
a
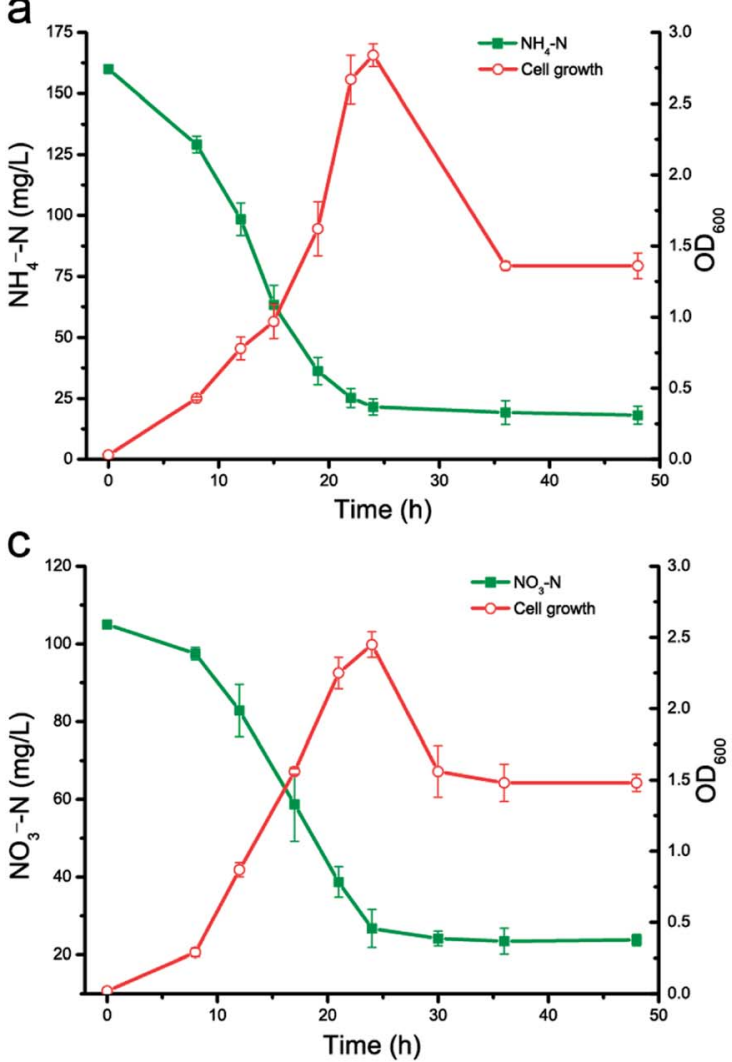

b
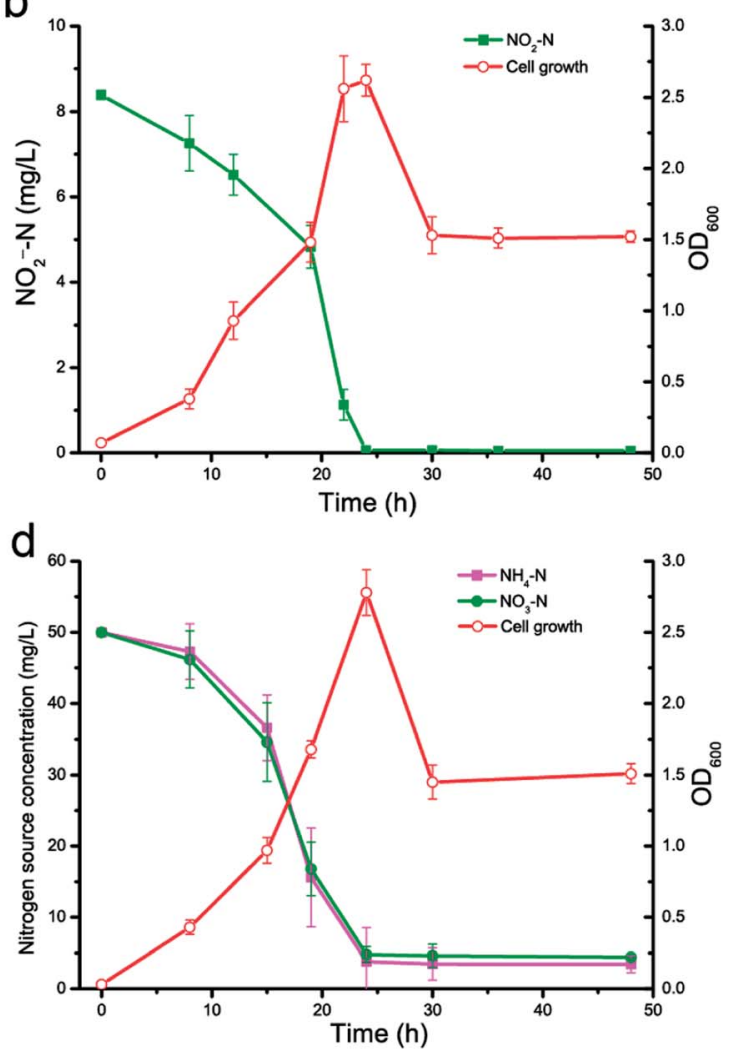

Fig. 1 Nitrogen removal and cell growth of strain $\mathrm{KSND}$ using (a) $\mathrm{NH}_{4}{ }^{+}-\mathrm{N}$, (b) $\mathrm{NO}_{2}{ }^{-}-\mathrm{N}$, (c) $\mathrm{NO}_{3}{ }^{-}-\mathrm{N}$ and (d) $\mathrm{NH}_{4} \mathrm{NO}_{3}-\mathrm{N}$ as sole nitrogen source.

was converted to intracellular nitrogen, and $\sim 68.9 \%$ was denitrified by KSND after $48 \mathrm{~h}$ in culture.

With further denitrification by KSND, a significant reduction in $\mathrm{NO}_{2}{ }^{-} \mathrm{N}$, the sole nitrogen source, was observed at $24 \mathrm{~h}$ (Fig. 1b), and $\sim 100 \%$ of the initial nitrite $\left(8.39 \mathrm{mg} \mathrm{L}^{-1}\right)$ was removed, with an average removal rate of $0.35 \mathrm{mg} \mathrm{L}^{-1} \mathrm{~h}^{-1}$. When $\mathrm{NO}_{3}{ }^{-}-\mathrm{N}$ was the nitrogen source, it decreased significantly from $105 \mathrm{mg} \mathrm{L}^{-1}$ initially to $26.75 \mathrm{mg} \mathrm{L}^{-1}$ (Fig. 1c). Approximately $74.52 \%$ of the nitrate was removed and the corresponding maximum removal rate was $3.26 \mathrm{mg} \mathrm{L}^{-1} \mathrm{~h}^{-1}$, which was higher than that of Pseudomonas tolaasii strain Y-11 $\left(1.99 \mathrm{mg} \mathrm{L}^{-1} \mathrm{~h}^{-1}\right)^{13}$ and Rhodococcus sp. CPZ24 (0.93 $\left.\mathrm{mg} \mathrm{L}^{-1} \mathrm{~h}^{-1}\right){ }^{14}$ Ammonium nitrate was used to investigate the simultaneous nitrification and denitrification capacity of KSND (Fig. 1d). The concentration of $\mathrm{NH}_{4}{ }^{+}-\mathrm{N}$ of $50 \mathrm{mg} \mathrm{L}^{-1}$ decreased to $3.82 \mathrm{mg} \mathrm{L}^{-1}$ after $24 \mathrm{~h}$, with a removal efficiency of $92.36 \%$ and a removal rate of $1.92 \mathrm{mg} \mathrm{L}^{-1}$ $\mathrm{h}^{-1}$. Nitrate decreased from 50 to $4.80 \mathrm{mg} \mathrm{L}^{-1}$, with a removal efficiency of $90.40 \%$ and a removal rate of $1.88 \mathrm{mg} \mathrm{L}^{-1} \mathrm{~h}^{-1}$. These results indicate that KSND had no preference among the nitrogen sources and differs from $P$. tolaasii $\mathrm{Y}-11$ and $K$. variicola sd-3 in that it more efficiently nitrifies ammonium than it denitrifies nitrate. ${ }^{10,13}$ Furthermore, the accumulation of nitrite was undetectable during the aerobic nitrogen removal process. This phenomenon may be attributable to the rapid removal by nitrite reductase of the trace nitrite produced by denitrification. Taken together, these results suggest that strain KSND has a broad substrate utilization capacity and efficient simultaneous nitrification and aerobic denitrification capabilities.

\subsection{Factors affecting nitrogen removal by KSND}

The effect of the $\mathrm{C} / \mathrm{N}$ ratio (1-20) on the nitrogen removal efficiency of strain KSND is shown in Fig. 2a. The residual nitrogen removal activities were more than $35 \%, 56 \%$, and $73 \%$ for $\mathrm{C} / \mathrm{N}$ values of 1,4 , and 6 , respectively. This result differs from that for Zobellella taiwanensis $\mathrm{DN}-7$, in which higher $\mathrm{C} / \mathrm{N}$ ratios $(>12)$ resulted in a serious deterioration in ammonium removal. ${ }^{12}$ These results suggest that strain KSND is over excellent denitrifiers such as Bacillus strain $\mathrm{N} 31$ and B. methylotrophicus $L 7$, even at high $\mathrm{C} / \mathrm{N}$ ratios of $6-20 .^{15,16}$ Therefore, strain KSND offers an alternative bacterium for the remediation of low-C/N domestic wastewater.

KSND showed efficient nitrogen removal over a wide range of initial pHs (5.0-8.0), with approximate removal rates of 91-92\%. More than $68 \%$ and $47 \%$ of this activity remained at $\mathrm{pH} 9.0$ and pH 10.0, respectively (Fig. 2b). Strain KSND showed an optimal temperature for nitrogen removal of $35{ }^{\circ} \mathrm{C}$. However, even at $10{ }^{\circ} \mathrm{C}$, it maintained a removal rate of almost $63 \%$ (Fig. 2c). Previous reports have suggested that aerobic denitrification is seriously reduced below $10^{\circ} \mathrm{C}$ because of the consequent delay in cell growth and nitrogen metabolism. ${ }^{17}$ Our results indicate that strain KSND can be used for low-temperature nitrification and denitrification. The temperature of most environmental water is $<20^{\circ} \mathrm{C}$, suggesting the potential application of KSND to wastewater treatment in wintertime or in open reactors.

The effects of the ammonium concentration on cell growth, ammonium removal, and the nitrification products 
a

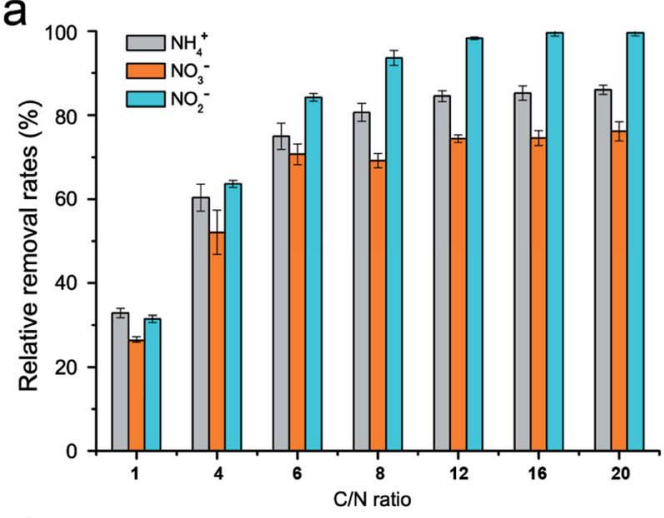

C

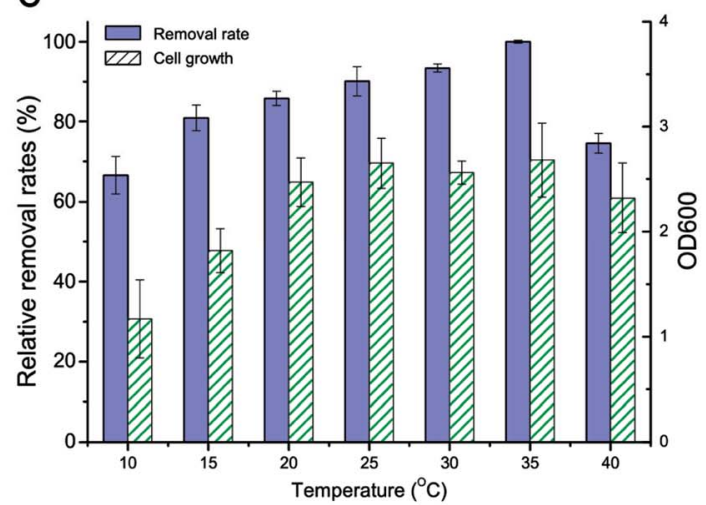

b

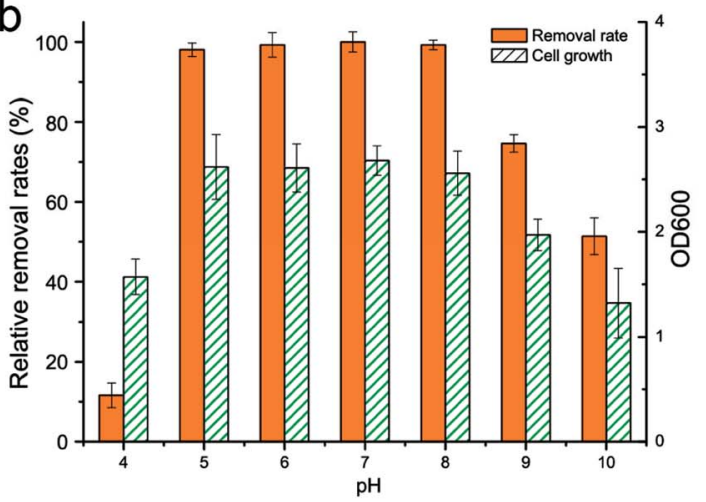

d

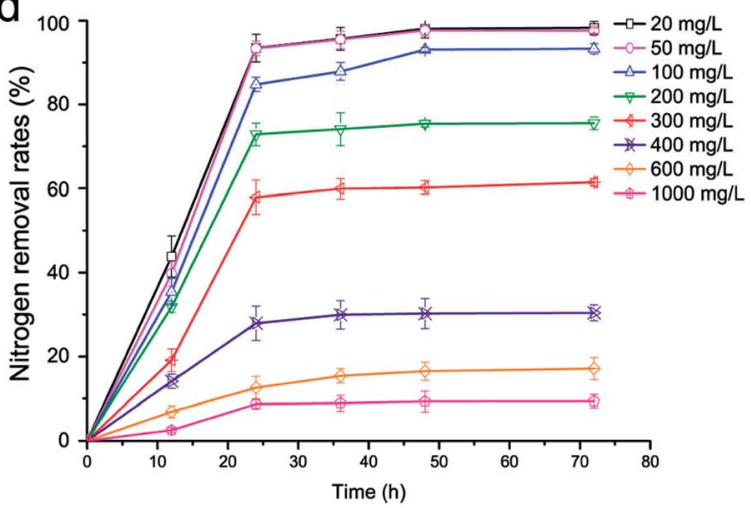

Fig. 2 Analysis of the factors on the nitrogen removal efficiency of strain KSND. (a) $\mathrm{C} / \mathrm{N}$ ratio, (b) $\mathrm{pH}$, (c) temperature and (d) ammonia concentration. The relative removal rate is represented as a percentage of the maximum removal efficiency.

were evaluated. Higher $\mathrm{NH}_{4}{ }^{+}-\mathrm{N}$ concentrations resulted in slightly higher cell growth, indicating that KSND tolerates a broad range of ammonium concentrations. After culture for $24 \mathrm{~h}$, ammonia was removed at average rates of $0.78,1.94$, $3.53,6.07,7.23,4.65,3.15$, and $3.62 \mathrm{mg} \mathrm{L}^{-1} \mathrm{~h}^{-1}$ in $\mathrm{NH}_{4}{ }^{+}-\mathrm{N}$ concentrations ranging from 20 to $1000 \mathrm{mg} \mathrm{L}^{-1}$, respectively (Fig. 2d). No accumulation of the nitrification product $\mathrm{NO}_{2}{ }^{-}$ $\mathrm{N}$ was detectable (data not shown). The high-strength ammonium probably inhibited the enzyme activities involved in nitrification, which would account for the deterioration in the ammonium removal efficiency. By contrast, aquaculture water, effluent, and domestic wastewater have relatively low ammonium levels, ranging from 0.2 to $200 \mathrm{mg} \mathrm{L}^{-1} .^{18,19} \mathrm{KSND}$ removed $93.10 \%$ of the initial $\mathrm{NH}_{4}{ }^{+}-\mathrm{N}$ $\left(100 \mathrm{mg} \mathrm{L}^{-1}\right)$ within $24 \mathrm{~h}$. This is highly significant for the practical application of KSND to most sewage treatments, including of aquaculture water, general effluent, domestic sewerage, and other wastewaters containing low levels of ammonia.

\subsection{Determination of the genes involved in nitrogen metabolism}

A phylogenetic analysis of $16 \mathrm{~S}$ rRNA genes showed that the isolated strain KSND is affiliated with the genus Klebsiella (Fig. 3a). Genes encoding functional enzymes involved in the nitrification (Hao) and denitrification pathways (dissimilatory NirS) are often used as biomarkers to detect denitrifiers. ${ }^{20}$ Neither the hao nor nirS gene could be detected in the KSND strain with PCR and specific degenerate primers, whereas these primers highly efficiently amplified the hao and nirS genes from the environmental samples (Fig. 3b). These results are almost consistent with a previous report of $K$. pneumoniae EGD-HPI9-C. ${ }^{11}$ Therefore, the traditional nitrification and denitrification pathways are incomplete in Klebsiella sp. strain KSND, indicating a metabolic versatility in its nitrification and denitrification reactions. Recently, it is indicated that may be existed the other denitrification pathway via hydroxylamine intermediate. ${ }^{10,21,22}$ This matter requires further investigation to clarify the simultaneous nitrification and denitrification processes of this strain.

\subsection{Efficient nitrogen removal to a domestic sewerage system}

Strain KSND was used to remove ammonia nitrogen from a river, using a floating bed carrying a simple bioreactor (Fig. 4a). The cell growth of KSND was $\sim \mathrm{OD}_{600}=1.7\left(\sim 6.3 \pm 0.5 \times 10^{7}\right.$ colonyforming units per $\mathrm{mL}$ ) after intense culture for $24 \mathrm{~h}$ in the bioreactor. $\mathrm{NH}_{4}{ }^{+}-\mathrm{N}\left(8.76 \mathrm{mg} \mathrm{L}^{-1}\right)$ was present in the river, with undetectable amounts of $\mathrm{NO}_{3}-\mathrm{N}$ and $\mathrm{NO}_{2}-\mathrm{N}$. After 14 days, the $\mathrm{NH}_{4}{ }^{+}-\mathrm{N}$ concentration was dramatically reduced to $5.78 \mathrm{mg} \mathrm{L}^{-1}$ (Fig. $4 \mathrm{~b}$ ). $\mathrm{NO}_{3}-\mathrm{N}$ and $\mathrm{NO}_{2}-\mathrm{N}$ were not detected during this time, which clearly differs from the results for Enterobacter cloacae CFS27.22 Most studies have shown that nitrite accumulation is 
a

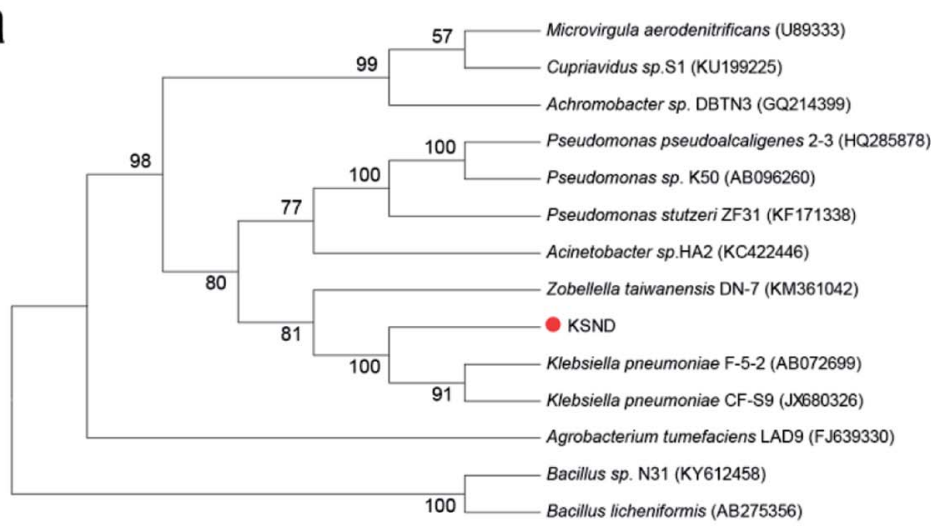

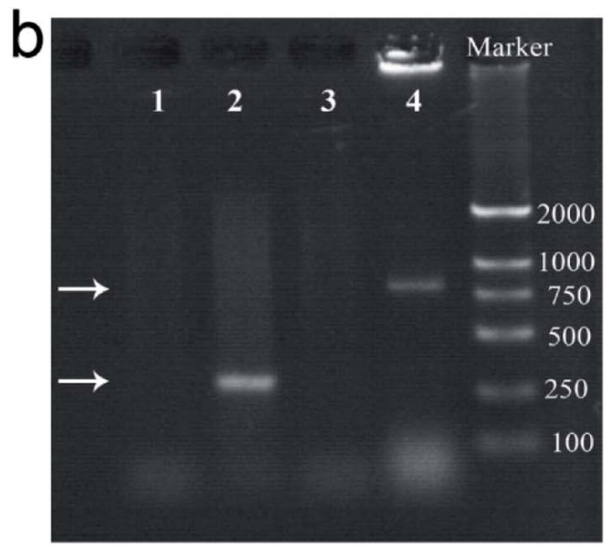

Fig. 3 Phylogram and biomarkers detection of strain KSND. (a) Phylogenetic analysis based on the 16S rRNA gene sequence of KSND using the neighbor-joining (NJ) method. (b) PCR amplification of Hao and NirS genes in strain KSND and control sample (metagenomic DNA). Lane 1 (KSND) and lane 2 (control) for NirS detection; lane 3 (KSND) and lane 4 (control) for Hao detection.

a

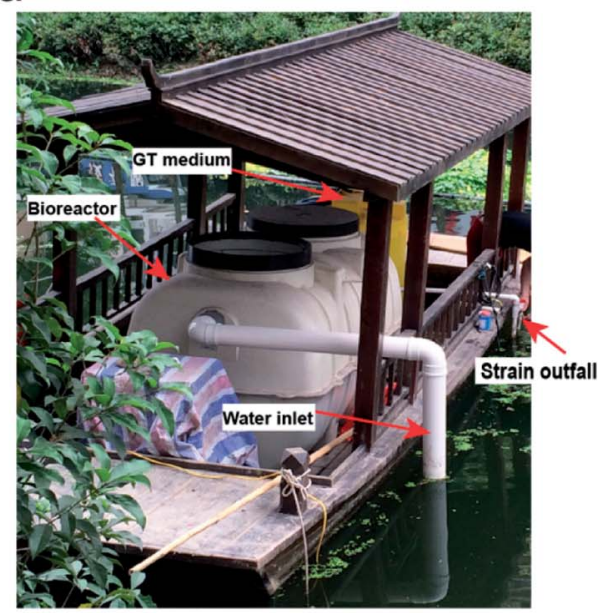

b

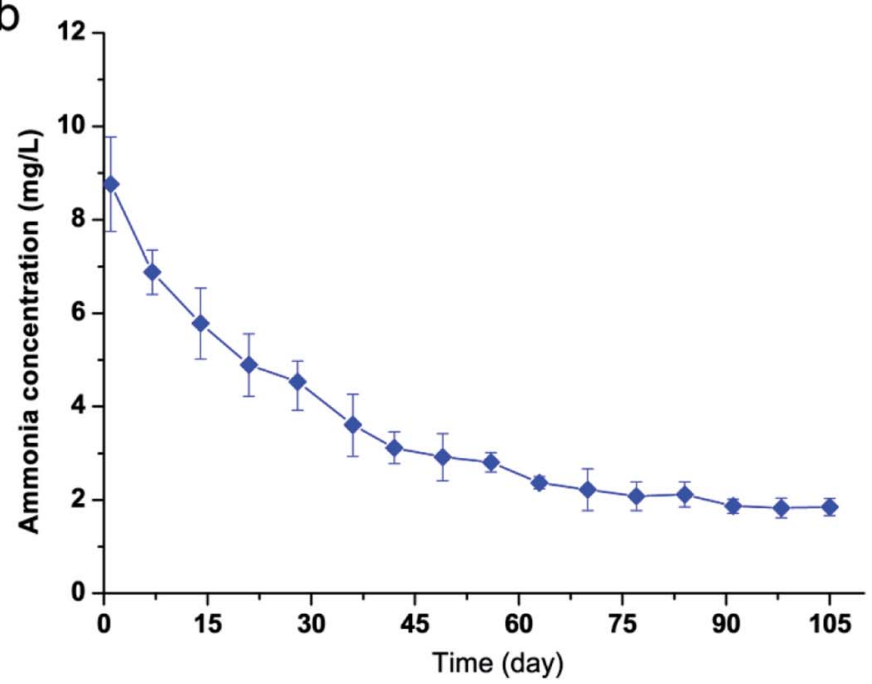

Fig. 4 Determination of the nitrogen removal performance of KSND strain applied in river restoration. (a) Bioreactor on floating-bed; (b) ammonia nitrogen profile for the operational period with application of strain KSND.

inevitable during the biological treatment of wastewater, which reduces the removal efficiency of $\mathrm{TN}$. Nitrite nitrogen is a compound with particularly high toxicity to freshwater animals and environmental bacteria. ${ }^{23}$ Our results indicate that KSND caused no toxic compound pollution during the large-scale treatment of sewage. After 91 days, the $\mathrm{NH}_{4}{ }^{+}-\mathrm{N}$ concentration was further reduced to $1.87 \mathrm{mg} \mathrm{L}^{-1}$ (Fig. 4b), and this level was maintained throughout the experiment (180 days). Overall, our study shows the excellent performances of KSND as a nitrogen remediator and its great potential utility in the removal of nitrogen from domestic wastewater and in river restoration.

\section{Conclusions}

In this study, a simultaneously nitrifying and denitrifying strain, Klebsiella sp. KSND, was successfully isolated, and demonstrated an excellent capacity for the simultaneous removal of high concentrations of ammonium, nitrite, and nitrate, with maximal removal rates of $5.77,0.35$, and $3.26 \mathrm{mg} \mathrm{L}^{-1} \mathrm{~h}^{-1}$, respectively. The average removal efficiency at $10{ }^{\circ} \mathrm{C}$ or in low-C/N wastewater was above $50 \%$. This excellent performance makes KSND a promising candidate remediator of nitrogen pollution, with particular applications in nitrogen removal from low-C/N domestic wastewater.

\section{Conflicts of interest}

The authors declare no competing financial interest.

\section{Acknowledgements}

This work was supported by the National Natural Science Foundation of China (Grant 31700078 and Grant 31270724), the Scientific Research Foundation for Talent program of Zhejiang Agricultural and Forestry University (W20170029), Distinguished Scholars of Zhejiang Agricultural and Forestry University (2014FR064). 


\section{References}

1 J. N. Galloway, A. R. Townsend, J. W. Erisman, M. A. Bekunda, Z. Cai, J. R. Freney, L. A. Martinelli, S. P. Seitzinger and M. A. Sutton, Science, 2008, 320, 889-892.

2 J. C. Finlay, G. E. Small and R. W. Sterner, Science, 2013, 342, 247-250.

3 J. Granger and S. D. Wankel, Proc. Natl. Acad. Sci. U. S. A., 2016, 113, E6391-E6400.

4 G. Zhu, Y. Peng, B. Li, J. Guo, Q. Yang and S. Wang, Rev. Environ. Contam. Toxicol., 2008, 192, 159-195.

5 Y. Shi, S. Hu, J. Lou, P. Lu, J. Keller and Z. Yuan, Environ. Sci. Technol., 2013, 47, 11577-11583.

6 Y. Wu, S. Shukal, M. Mukherjee and B. Cao, Environ. Sci. Technol., 2015, 49, 11551-11559.

7 M. Strous, E. Pelletier, S. Mangenot, T. Rattei, A. Lehner, M. W. Taylor, M. Horn, H. Daims, D. Bartolmavel and P. Wincker, Nature, 2006, 440, 790-794.

8 Z. Jing, L. Feng, G. Yang, D. Chen and J. Mu, Bioresour. Technol., 2017, 243, 800-809.

9 S. K. Padhi, S. Tripathy, R. Sen, A. S. Mahapatra, S. Mohanty and N. K. Maiti, Int. Biodeterior. Biodegrad., 2013, 78, 67-73.

10 Y. Feng, J. Feng and Q. Shu, J. Appl. Microbiol., 2018, 124, 1195-1211.

11 R. R. Pal, A. A. Khardenavis and H. J. Purohit, Funct. Integr. Genomics, 2015, 15, 63-76.
12 L. Yu, Y. Wang, H. Liu, C. Xi and L. Song, Appl. Microbiol. Biotechnol., 2016, 100, 4219-4229.

13 H. Tengxia, L. Zhenlun, S. Quan, X. Yi and Y. Qing, Bioresour. Technol., 2016, 200, 493-499.

14 P. Chen, J. Li, Q. X. Li, Y. Wang, S. Li, T. Ren and L. Wang, Bioresour. Technol., 2012, 116, 266-270.

15 Q. L. Zhang, Y. Liu, G. M. Ai, L. L. Miao, H. Y. Zheng and Z. P. Liu, Bioresour. Technol., 2012, 108, 35-44.

16 F. Huang, L. Pan, N. Lv and X. Tang, J. Biosci. Bioeng., 2017, 124, 564-571.

17 S. Saleh-Lakha, K. E. Shannon, S. L. Henderson, C. Goyer, J. T. Trevors, B. J. Zebarth and D. L. Burton, Appl. Environ. Microbiol., 2009, 75, 3903-3911.

18 S. Tsukuda, L. Christianson, A. Kolb, K. Saito and S. Summerfelt, Aquacult. Eng., 2015, 64, 49-59.

19 R. Crab, Y. Avnimelech, T. Defoirdt, P. Bossier and W. Verstraete, Aquaculture, 2007, 270, 1-14.

20 M. Li, T. Ford, X. Li and J. D. Gu, Environ. Sci. Technol., 2011, 45, 3547-3553.

21 B. Zhao, Y. L. He, J. Hughes and X. F. Zhang, Bioresour. Technol., 2010, 101, 5194-5200.

22 S. K. Padhi, S. Tripathy, S. Mohanty and N. K. Maiti, Bioresour. Technol., 2017, 232, 285-296.

23 A. Alonso and J. A. Camargo, Ecotoxicol. Environ. Saf., 2009, 72, 2005-2008. 